\title{
Erratum to: Generation of Pig iPS Cells: A Model for Cell Therapy
}

\author{
Núria Montserrat • Elena Garreta Bahima • Laura Batlle • \\ Sophia Häfner • Alexandre Miguel Cavaco Rodrigues • \\ Federico González • Juan Carlos Izpisúa Belmonte
}

Published online: 31 August 2012

(C) Springer Science+Business Media, LLC 2012

Erratum to: J. of Cardiovasc. Trans. Res.

DOI 10.1007/s12265-010-9233-3

One panel from Fig. 1 and one panel from Fig. 4 were mixed up with that of another manuscript which we published (Cell Transplantation, Volume 21, Number 5, 2012, pp. 815-825) during submission of this manuscript. This has now been corrected. This oversight in no way affects any of the other data or conclusions drawn in our paper. The authors apologize for this error.

The online version of the original article can be found at http://dx.doi.org/ 10.1007/s12265-010-9233-3.

N. Montserrat $\cdot$ L. Batlle $\cdot$ S. Häfner $\cdot$ A. M. Cavaco Rodrigues •

F. González · J. C. Izpisúa Belmonte

Center of Regenerative Medicine of Barcelona (CMRB),

Doctor Aiguader 88, p7,

08003 Barcelona, Spain

E. Garreta Bahima

Unitat de Biofísica i Bioenginyeria,

Facultat de Medicina Casanova 143,

08036 Barcelona, Spain

J. C. Izpisúa Belmonte ( $\bowtie)$

Salk Institute for Biological Studies,

10010 North Torrey Pines Road,

La Jolla, CA 92037, USA

e-mail: belmonte@salk.edu

J. C. Izpisúa Belmonte

e-mail: izpisua@cmrb.eu 
a
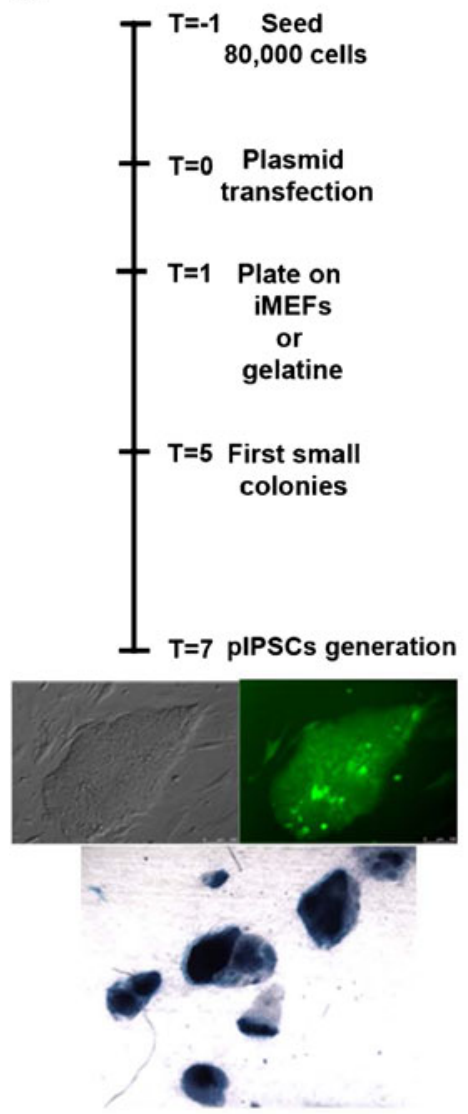

b
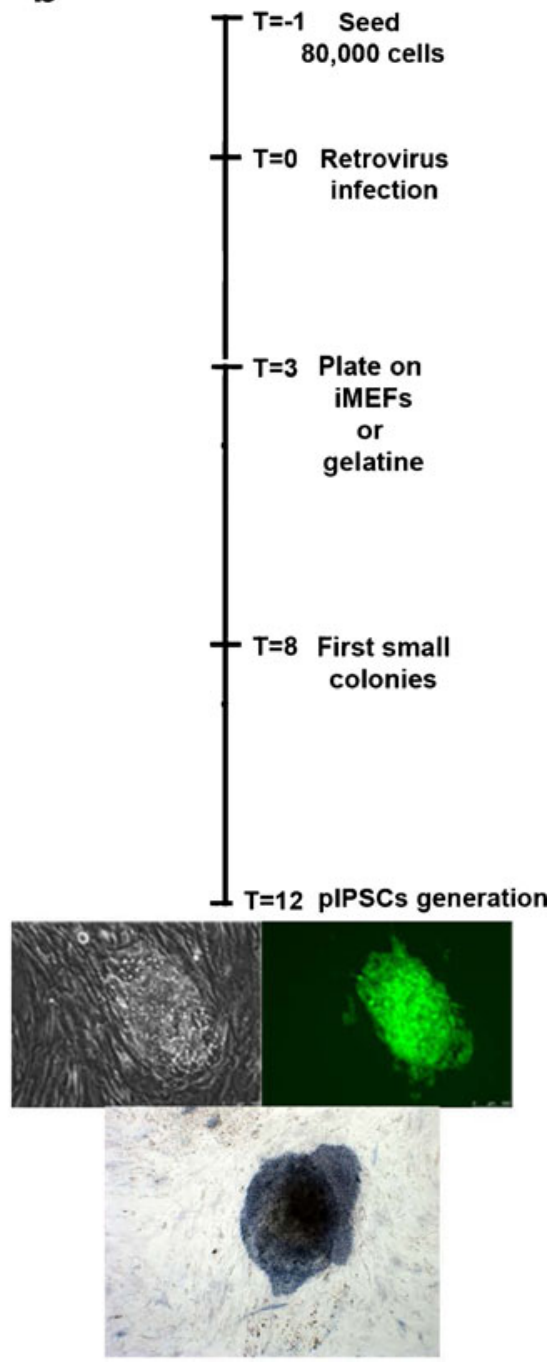

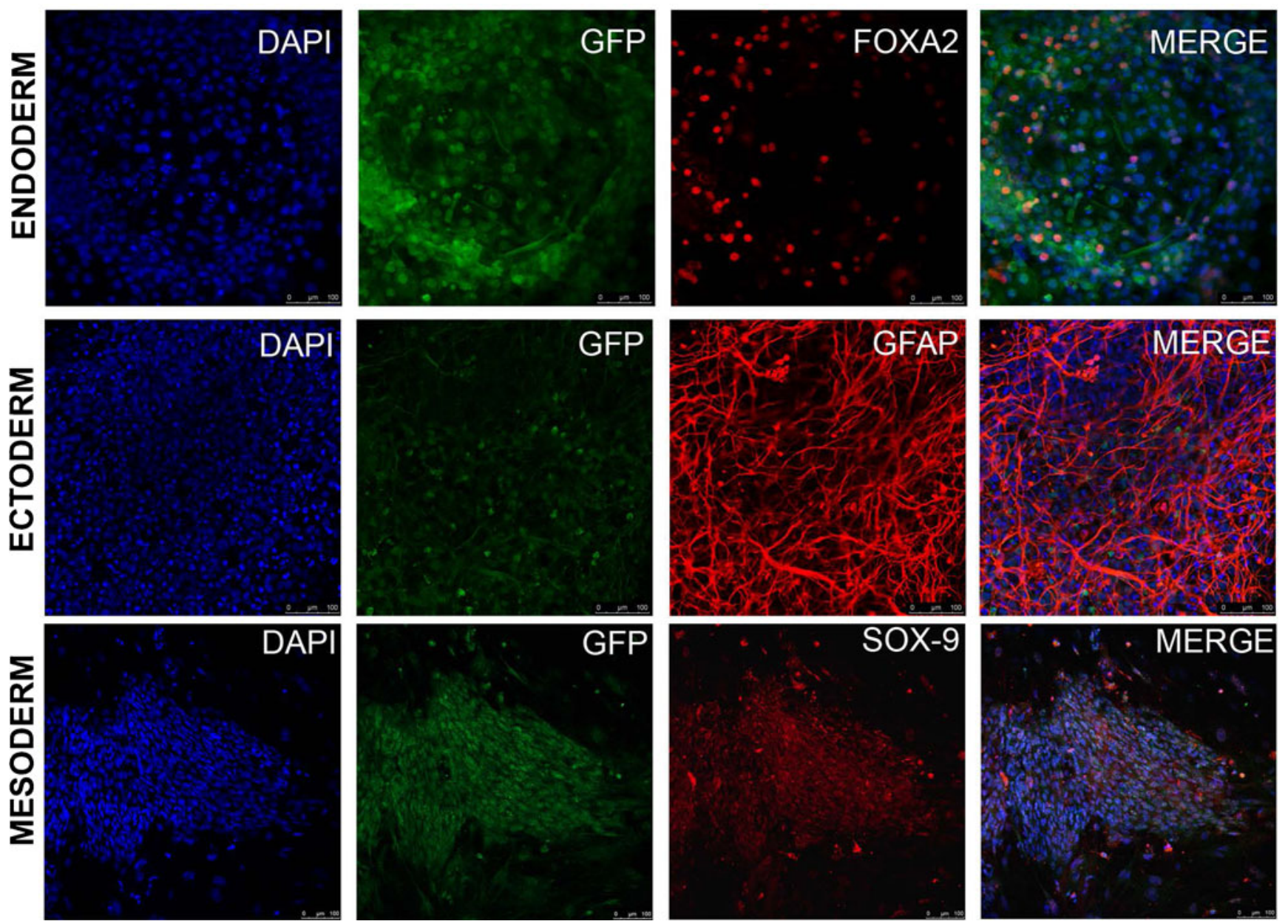